\title{
Szabálykövetó drónhasználat az ELTE-n: milyen feltételeknek kell megfelelnünk, hogy repülhessünk?
}

\author{
PÁL Márton - H. VÖRÖS Fanni - KOVÁCS Béla
}

DOI: $10.30921 / G K .73 .2021 .5 .3$

\begin{abstract}
Absztrakt: A drónos távérzékelés és fotogrammetria a 21. század egyik leggyorsabban terjedô és fejlődō tudományterülete. A pilóta nélküli légi jármüvek (Unmanned Aircraft - UA, Unmanned Aerial Vehicle - UAV), illetve légijármü-rendszerek (Unmanned Aerial Systems - UAS) fejlett adatnyerési lehetốségei és az ezekból fakadó sokrétú alkalmazhatóság révén számos gazdasági szektorban nagy jelentốséggel bírnak már napjainkban is. Az építôipar, az energetika, a logisztika, a katonaság, a mezögazdaság, a természettudományhoz kötôdô ipari ágazatok, valamint a környezetvédelem mind-mind használnak légi fényképeket, 2D-s vagy 3D-s térinformatika-alapú térképeket és modelleket. Mindezek miatt a drónok szerepe az oktatásban is egyre jelentốsebb: egyre nagyobb az igény a fejlett adatnyerési és adatfeldolgozási lehetôségeket ismerố szakemberek iránt. Karunk az oktatási, kutatási és ipari lehetốségekre egyaránt fókuszálva szerezte be drónját, illetve szenzorait. Munkánkban áttekintést adunk tapasztalatainkról: milyen változások történtek a tavalyi évhez képest az UAV-ok szabályos használatával kapcsolatban, valamint milyen feltételek írják le a jogkövetố drón-és légtérhasználatot.
\end{abstract}

Abstract: UAV-based remote sensing and photogrammetry is one of the most booming and developing science and industrial sector of the 21th century. The modern data acquiring methods and various application possibilities of Unmanned Aerial Vehicles have great significance in numerous economic branches nowadays. Building and energy industry, logistics, military, agriculture, sectors connecting to geosciences, and even nature conservation also apply drone-sensed data, $2 \mathrm{D}$ maps, $3 \mathrm{D}$ models, or other GIS-related data. Because of this, the role of UAVs in education is becoming more important. Professionals in modern data acquisition and data processing (image analysis, mapping or model building) are demanded by various companies. Our faculty has decided to purchase a drone and two sensors (an RGB and a multispectral) to focus on educational, research and industrial applications. In our paper, we give a short overview of our experiences: what is the current legislative background of UAV flights in Hungary and what is the framework of categorizing drones and drone flights.

Kulcsszavak: drón, UAV, térinformatika, jogi szabályozás, távérzékelés, fotogrammetria

Keywords: UAV, GIS, legislative background, remote sensing, photogrammetry

\section{A drónok mint az adatnyerés modern eszközei}

A drónok alkalmazása ipari, honvédelmi, mezógazdasági és tudományos környezetben is dinamikusan terjed, egyre tágul a lehetőségek, ezzel együtt pedig a drónokat különféle célokkal kezelôk csoportja. Fogalmi meghatározásuk szakirodalomtól függôen más és más lehet - ez többnyire az adott felhasználási módtól függ. Általánosan azonban olyan viszonylag kis méretú légi jármúvekre gondolunk, amelyeket távolról, rádiókapcsolattal irányítunk, illetve felszerelésük alkalmassá teszi óket valamilyen feladat ellátására - legyen az egyszerú fényképkészítés vagy akár permetezés. Angol elnevezésük épp a fedélzeti kezelôszemélyzet hiányából fakad: az Unmanned Aerial Vehicle (UAV - pilóta nélküli légi jármú) és Unmanned Aerial Systems (UAS - pilóta nélküli légijármú-rendszerek) fogalmak nemzetközi szinten jól ismernek, és többnyire minden pilóta nélküli (távirányítással) fel- és leszállásra képes eszközt magukba foglalnak (Elliott 2017, Major et al. 2016, Restás 2017).

Az UAV-okat több szempontrendszer alapján tudjuk csoportosítani. Hajtásrendszerük szerint a villanymotoros gépek a legelterjedtebbek: ezek alkalmazása és karbantartása a legegyszerúbb. Léteznek azonban robbanómotoros és hibriddrónok is, amelyeket többnyire nagyobb teher szállítására, hosszabb repülési idóvel alkalmaznak. A merev szárnyú gépeket zömmel katonai feladatokra használják - polgári célokra elterjedtebbek a rotoros gépek, amelyeket rotorszám alapján is differenciálhatunk: pl. kvadrokopter 4 rotor, hexakopter -6 rotor (Major et al. 2016, Palik 2013).

A legpraktikusabb azonban a felszállás módja szerinti csoportosítás. Megkülönböztetünk vízszintesen (HTOL - Horizontal Take Off and Landing) és függólegesen felszálló (VTOL - Vertical Take Off and Landing) drónokat, de léteznek ezek különböző kombinációi is (Palik 2013). Repülési magasság és hatótávolság alapján definiálhatunk HALE (nagy magasságú és nagy hatótávolságú - high altitude, long endurance), MALE (közepes magasságú és nagy hatótávolságú - medium altitude, long endurance), LALE (alacsony magasságú és nagy hatótávolságú - low altitude, long endurance), és LASE (alacsony magasságú és rövid hatótávolságú - low altitude, short endurance) gépeket (Restás 2017).

Az ELTE (Eötvös Loránd Tudományegyetem) mint az ország legnagyobb kutatóegyeteme számára a drónos távérzékelés és fotogrammetria a tudományos és oktatási szempontok miatt elsődlegesen fontos. Emiatt esett választásunk egy nagypontosságú repülést és méréseket végző, két szenzort (payload, hasznos teher) is szállítani képes VTOL kvadrokopterre. Beszerzésre került egy RGB és egy hatcsatornás multispektrális kamera is, amelyeket akár egyidőben is a drónra tudunk szerelni. 
A geoinformatika mint modern tudományág nagy hangsúlyt fektet a térbeliséggel bíró adatok feldolgozására, valamint az ezekbőll levezetett adatok előállítására. Munkánkban két fố szempontra fókuszálunk: a jelenlegi (és közelmúltbeli) jogi háttérre, amely követésével szabályosan repülhetünk, valamint néhány térképészeti és geoinformatikai szempontból érdekes alkalmazási lehetôségre. A törvényi változások bemutatása kifejezetten aktuális a teljes mértékben 2021. február 10-én életbe lépô új „dróntörvény” miatt, hiszen ez jelentôs szemlélet- és gyakorlatváltást hozott a hazai UAV-ok jogi kezelésében. A néhány példa bemutatását pedig a folyamatosan bôvülő szoftveres, hardveres és elméleti-tudományos lehetôségek miatt tartjuk fontosnak: képet adhatunk arról, hogy a hazai térképészetnek jelenleg milyen lehetôségei vannak a drónhasználatban.

\section{Az ELTE Informatikai Kar új drónja}

$\mathrm{Az}$ 1. ábra $\mathrm{A}$ ) és $\mathrm{B})$ részén láthatók a drón azon részei, amelyeknek a felmérés és feldolgozás során fontosabb szerep jut. A C) részén az általunk használt két szenzor részei és elhelyezkedése látható. A D) részén az egyik szerző (PM) kezében az ELTE Térképtudományi és Geoinformatikai Intézet saját Stonex RTK GPS-e, illetve mellette (a múszerlábon) a drónhoz tartozó RTK-egység.

A DJI Matrice 210 RTK V2 UAV egy kvadrokopter, tehát négy rotor hajtja a repülőkarok végén elhelyezkedő propellereket (b). A karok végén, a propellerek alatt találhatók a jeladó antennák, amelyek a távirányító és a repülőeszköz közötti kommunikációt biztosítják (a). A karokat egy bilinccsel rögzíthetjük repülési állásba (n). A repülés biztonságáért és az akadályok elkerüléséért több szenzor és fényjelzés is felel; két erôs villogó LED (alul és fölül a $\mathrm{k}$ betûvel jelölve), a két elülsô (c) és az alsó (1) vizuális érzékelők, valamint a dróntest tetején elhelyezkedố infravörös szenzor segíti a baleset-megelốzést. Ezek mellett egy $608 \times 448$ px felbontású FPV (firstperson view) kamera (d) található az UAV-on, amely abban az esetben segíthet a tájékozódásban, ha egy felszerelt nagyobb felbontású kamera (esetünkben Zenmuse X5S - f-el jelölve) a földfelszínt pásztázza. A DLS 2 (Downwelling Light Sensor) fényszenzor (e) a multispektrális MicaSense Altum kamera (1) felvételei számára méri a fénysugárzás beesési szögét, illetve a környezet fényességét (amelyek alapján az 5 sáv képeit korrigálja, ld. lentebb,

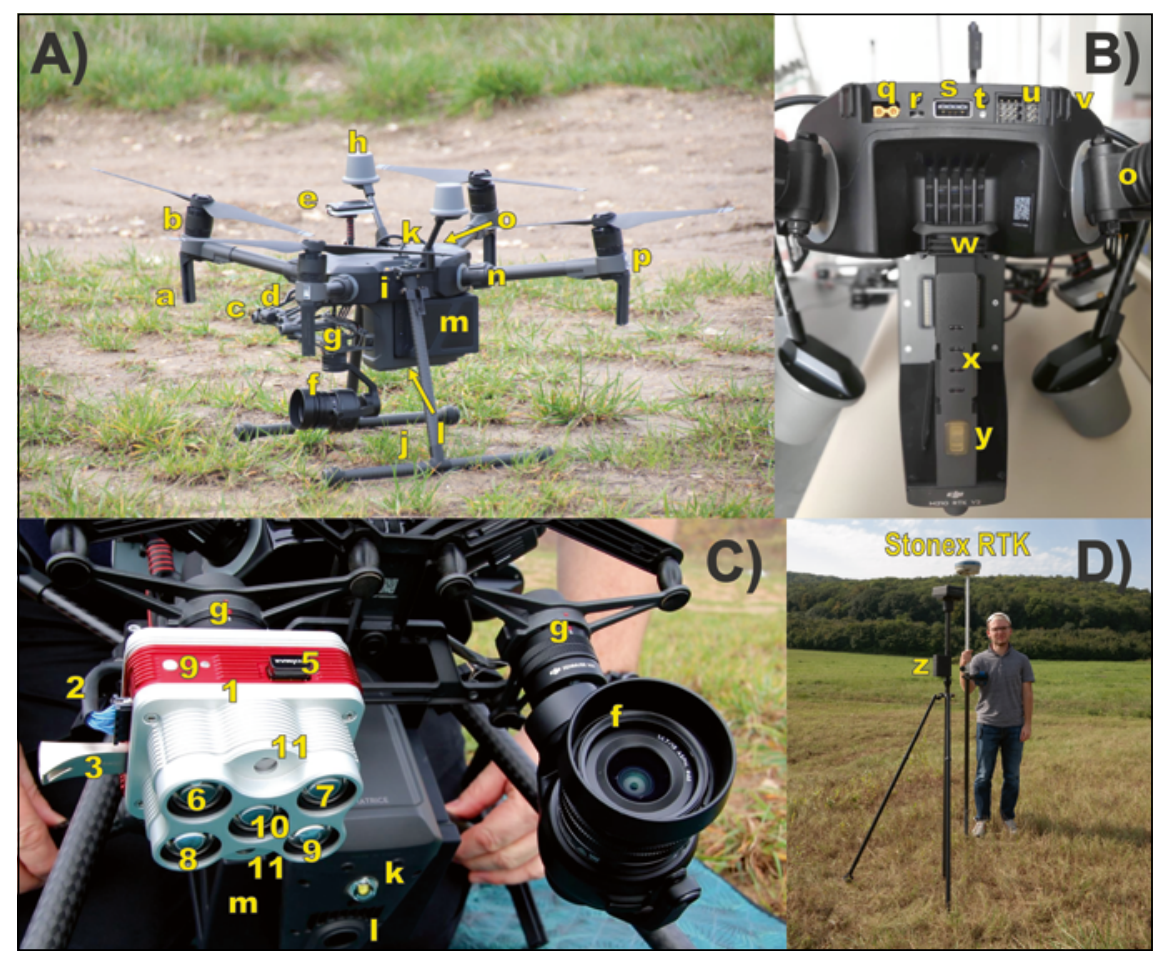

1. ábra. A drón részei A), B), a szenzorok felépitése (C),

valamint a mérések alkalmával használt RTK GPS-ek D)
MicaSense 2020). A drónhoz tartozó különálló RTK-állomás (z) által mért korrekciós adatok minél pontosabb érzékeléséért (a drón helyzetétől-irányától függetlenül) a két D-RTK-antenna a felelős (h). A fölszerelt szenzorok képeit egy, a drónba behelyezett SD-kártyára rögzítjük (i). Esetünkben ez csak a nagy felbontású Zenmuse kamera (f) esetében történik így, hiszen az Altum kamera csak tápellátást kap az UAV-tól, más kapcsolatban nincs vele. Az eszköz repüléséhez két akkumulátor (m) szükséges. A drón két lába (1) a biztos rögzítésnek köszönhetôen stabil indulást és landolást tesz lehetôvé. Az ESC (Electronic Speed Controller) LED-ek (mind a négy propellermotor oldalán - p-el jelölve) a gép állapotától és orientációjától (eleje/ hátulja) függóen piros-sárga-zöld színekkel világítanak (DJI 2020).

A drón hátoldalán többféle csatlakozót, gombot és visszajelzôt találunk. Az XT30-as külsố elektromos csatlakozó (q) más eszköznek biztosít tápellátást; az USB-mód kapcsolójával (r) az USB-porton (s) keresztüli kommunikáció irányát tudjuk beállítani; az eszközpárosító gombbal (t) külsố eszközt (pl. RTK - z-vel jelölve) tudunk az UAV-hoz társítani; a bôvítố tüskék (u) segítségével pedig a fejlesztôcsomagot megvásárlók tudják gazdagítani a drón képességeit. Az eszközállapot-jelzô LED-ek (v) fényei jelzik, hogy készen állunk a repülésre, csatlakozik-e RTK, illetve fennáll-e valamilyen komoly probléma (kalibráció, alacsony akkufeszültség), ami miatt nem szállhatunk fel. Az akkumulátorkioldó gomb (w) megnyomásával vehetjük ki az akkukat. A drón indításához meg kell nyomni egyszer röviden a bekapcsológombot (y) majd nyomva tartani, míg a rendszer önteszt múvelete el nem indul. Az töltöttségi szintet menet közben, valamint bekapcsolás nélkül röviden megnyomva a bekapcsológombot a visszajelzô LED-ek (x) segítségével ellenôrizhetjük (DJI 2020).

A 210-es gépre azonos időben két szenzor csatlakoztatható a speciális DJI Skyport (g) segítségével. Intézetünk esetében két érzékelô áll rendelkezésre. A Zenmuse X5S nagy felbontású RGB-kamerát (f) a felszín és egyéb objektumok felvételezésére (kép és videó) használjuk. 
A MicaSense Altum multispektrális szenzor (1) az elektromos ellátást a dróntól kapja (g, 2), de egyéb kapcsolat jelenleg nincs közöttük; állapotát egy visszajelzô LED (9) segítségével figyelhetjük. Külön wifiképes eszközzel, a kamera saját kezelôfelületén tudjuk a kép készítéséhez szükséges paramétereket beállítani (pl. átfedés mértéke, tárterület formázása). A repülés közben készült felvételeket egy pendrive-on (3) tároljuk, míg a wifikapcsolatot az Altumba csatlakoztatott adapter (5) biztosítja. Egy idôpillanatban hat különbözô spektrális sávú felvétel készül: közeli infravörös (6), vörös (7), kék (8), zöld (9), RedEdge (10) és egy kis felbontású termális (11).

\section{Hogyan repültünk szabályosan 2021 elejéig?}

2020 őszén, Bajna külterületén egy eocénprogram részeként a külszíni szénbányászattal felszíni tájsebet létrehozó, majd azt késôbb rekultivált bányatóvá átminôsített területen repültünk. UAV-eszközünkkel multispektrális és RGB-felvételeket készítettünk egy egyetemi kutatási projekt részeként. Az ekkor érvényes jogszabályok szerint jártunk el maradéktalanul:

- Elsố lépés a helyszíni terepszemle volt, ami gyakorlatilag a megközelíthetôség, terepi adottságok (parkolás, felszállóhely, akadályok és vészhelyzeti lehetôségek) elemzéséból állt (ha ismert a terület, akkor is szükséges a helyszíni bejárás, hiszen pilótaszemmel is fel kell mérni a környezet tulajdonságait és a potenciális veszélyforrásokat - pl. távvezetékek, fák, madarak). A terepszemlét megelôzheti/kiegészítheti a jogi viszonyok tisztázása: kié a terület, esetleg milyen különleges engedélyek szükségesek, kell-e a hatósági légtérfoglaláson kívül egyéb engedély (pl. természetvédelem, honvédség, önkormányzat, tulajdonos).

- A következô lépés a hatósági engedély(ek) beszerzése, valamint biztosítás megkötése (ha nem volt megelôzốen). Esetünkben a külterületen lévő „bányató” nem „aktív”, nem természetvédelmi területen van, nincs egyéb speciális engedélyekre szükség, kizárólag az eseti légtérigénylést kellet intézni. Mindez egy általánosan
3000 forintba kerülő, a tervezett repülést megelôzốen min. 30 nappal korábban benyújtott elektronikus nyomtatvány (ÁNYK-val kitöltve, ügyfélkapun keresztül benyújtva). Ez számunkra a kutatási tevékenység miatt illetékmentes volt. Az engedélyt maximum 30 napra lehetett igényelni, tehát az esetleges idôjárási zavaró tényezôk áthidalására volt 30 napunk (pl. egy esôs héten, egy szeles/viharos/zivataros időszakban drónnal nem biztonságos repülni - sốt tilos is).

- Az eseti légtérkijelölésérôl/kérelmünk elfogadásáról a hatóság egy határozatot küldött (pár napon vagy héten belül), amelyen fel vannak tüntetve a kért légterünk földrajzi (WGS84, fi/ lambda) és magassági (tipikusan AGL - Above Ground Level) határai. Amíg ez az engedély nem volt birtokunkban, a repülés az adott terület felett tiltott volt.

- Az engedély birtokában a tervezett repülés napján, már a terep megközelítésekor be kellett jelentenünk a hatóságnak légterünk használatbavételi igényét (telefonon), ahol engedélyezték ennek használatát (mindezt 30-60 perccel a tervezett felszállás előtt voltunk kötelesek megtenni).

- A terepre érve az UAV-eszközünk felszállás elốtti ellenôrzési listáján végigmenve már repülhetünk is. Mi általában tervezett útvonalon (vagyis elôre programozott magasságban, sebességben és nyomvonalon) repülünk az eszközünkkel, hisz csak így biztosítható az utófeldolgozás után elvárt végsố pontosság (akár 2-10 cm-es felbontás). A felhasznált szenzoroktól függóen (és persze az elvárt pontossági igényeink függvényében) a repülési magasság 50-120 m AGL között kell legyen. Alacsonyabb repülés esetén a területünkrôl ugyan elvileg nagyobb felbontású felvételeket készíthetünk, viszont az elvárt 70-80\%-os képátfedés miatt ez nagyságrendekkel megnövelheti a repülési idôt. Így is egy kb. 3 hektáros terület felmérése 3 akkumulátorszettet (esetünkben kb. 90 percnyi repülési idő) merített le, aminek töltése/pótlása terepen igencsak nehézkes.

- A repülés befejezését követően, a tereprôl levonuláskor egy újabb hívással kötelesek vagyunk „leállítani” a légtérfoglalásunkat az adott napra.
Ilyenkor a hatóság törli az online adatbázisból a területünkre érvényes repülési korlátozást.

- A hatóság a terepi repülésünk alkalmával bármikor földre parancsolhatja az UAV-eszközünket (emiatt kell megadni a kérelemben az adott repülésért felelôs személy elérhetôségét, akinek a tervezett repülés ideje alatt is folyamatosan elérhetônek kell lennie), amennyiben bármilyen nem várt légügyi esemény (pl. mentôhelikopter átrepülése) következne be.

- Amennyiben az eseti légteret hoszszabb idôre kértük, úgy az esetleges újabb repülés esetén az érvényességi határidôn belül csak a repülés napján elvégzett bejelentésre és lejelentésre volt szükségünk.

\section{Az új szabályozás keretei}

A magyar kormány az EU-s jogharmonizációs lépések keretében (az Európai Unió 2019/947. rendelete egyes kérdéseket tagállami hatáskörbe utalt) 2020. december 16-án elfogadta a 2020. évi CLXXIX. törvényt, amely három már eddig is létezô passzust módosít (a légi közlekedésról szóló 1995. XCVII. törvény (Lt.), a szabálysértésekrôl, eljárásokról és nyilvántartási rendszerrôl szóló 2012. II. törvény (Szabs. tv.) valamint a BTK 2012. évi C. törvényt (Btk.). Amit a köznyelv „dróntörvénynek” nevez, az valójában három már eddig is létezô törvény kiegészítése/módosítása és sok esetben szigorítása lett. Mindez a Magyar Közlöny 285. számában került kihirdetésre (2020. december 22-én) - 2021. január elsejei hatályba lépéssel (egyes pontjai esetén 2021. február 10-ig némi haladékot adva a törvénytisztelô felhasználóknak).

Az új, szigorúbb szabályozások alapja tehát egy EU-s rendelet/törvény honossá tétele volt. A magyar szabályozás többszöri halasztás után lépett törvényerôre. A szabályozás kiterjed minden UAV-eszközre. Az EU-s rendelettől sok esetben eltér (ezt a szigorítást a szabályozás lehetôvé teszi): szigorúbb feltételeket szab a drónokat kezelố pilótáknak, és a légi jármúveket is másképp kategorizálja.

A hazai szabályok a 120 gramm teljes felszállótömeg alatti, kamera/ képrögzítô nélküli légi jármúveket 
sorolják a „játék” kategóriába: ezekkel teljesen szabadon, bárhol, bármikor repülhetünk azzal a feltétellel, hogy az eszköz ne tudjon 100 m-nél nagyobb távolságra eltávolodni a pilótától. Az EU-s rendelet a 250 g-ot tekinti a $120 \mathrm{~g}$ helyetti határtömegnek. A piaci termékeket vizsgálva láthatjuk, hogy míg Európa nagyobb részében egy „normál, hobbicélú”, de akár 2/4k-s felbontású kamerával szerelt eszköz is viszonylag egyszerúen röptethetô, addig idehaza csak a nagyáruházak polcairól maximum pár 10 ezer forintért megvásárolt játékok esnek bele a kategóriába. Néhány gyártó pedig pont a 250 g-os tömeghatárra koncentrálva fejlesztett ki épp hogy könnyebb termékeket (pl. DJI Mavic Mini, Mini 2).

\section{A drónok gyártók általi osztályba sorolása}

Ahogy láthattuk, a múveleti kategóriák beosztása zömmel két tényezótôl, a be nem vont személyektốl való távolságtól és a drón paramétereitôl függ. Ez utóbbival kapcsolatos részletes követelmények a 2019/945 Felhatalmazáson alapuló rendeletben (EU 2019²) olvashatók. A gyártóknak ezek alapján C0/ C1/C2/C3/C4 osztályokba kell sorolniuk az eszközöket.

A C0 osztályba tartozó UAV-ok 250 g-nál könnyebbek, nem képesek 10 m-nél magasabbra repülni, vízszintesen max. $19 \mathrm{~m} / \mathrm{s}$-al képesek haladni, követési mód esetén max. 50 m-re tudnak eltávolodni a pilótától, valamint elektromos árammal kell múködniük (24 V egyenáram vagy ezzel egyenértékú váltakozó áram).

A C1 osztályú gépek az elôző kategóriától annyiban különböznek, hogy maximális tömegük $900 \mathrm{~g}$, rendelkezniük kell sorozatszámmal, GPSszel, távoli azonosításra alkalmas rendszerrel, valamint az éjszakai láthatóságot biztosító lámpákkal, amelyek révén egyértelmúen megkülönböztethetôk a pilótával rendelkezô repülôgépektôl.

A C2-es drónok hajthatnak végre múveleteket az A2-es kategóriában. Ennél fogva bizonyos esetekben akár 5 m-re is megközelíthetnek embereket. Felszállótömegük max. $4 \mathrm{~kg}$ lehet, 120 m-nél nem repülhetnek magasabbra (ha képesek rá, a funkció legyen korlátozható), rendelkezzenek alacsony sebességú móddal, ahol a max. vízszintes sebesség $3 \mathrm{~m} / \mathrm{s}$, elektromos árammal múködjenek (48 V egyenáram vagy ezzel egyenértékú váltakozó áram), legyenek ellátva sorozatszámmal, GPS-szel, távoli azonosításra alkalmas rendszerrel, valamint éjszakai láthatóságot biztosító lámpákkal, amelyek révén egyértelmúen megkülönböztethetôk a pilótával rendelkezô repülôgépektől.

A C3 osztályba azok a nagyobb drónok kerülnek, amelyekre a következő feltételek igazak: szerkezetük könnyebb, mint $25 \mathrm{~kg}$, méretük 3 m-nél kisebb, 120 m-nél nem repülnek magasabbra (ha képesek rá, a funkció legyen korlátozható), elektromos árammal múködnek (48 V), van sorozatszámuk, GPS-ük, távoli azonosításra alkalmas rendszerük, valamint rendelkeznek éjszakai láthatóságot biztosító lámpákkal, amelyek révén egyértelmúen megkülönböztethetôk a pilótával rendelkezố repülőgépektől.

A C4-es osztályú gépekre kevés kritériumot határoz meg a jogszabály: 25 kg-nál könnyebbnek kell lenniük, valamint ne lehessen ôket automatikusan irányítani.

\section{Repülés nyílt múveleti kategóriában}

A $120 \mathrm{~g}$ felszállótömeg fölötti (akár képrögzítóvel felszerelt) gépekkel ún. nyílt kategóriájú (A1/A2/A3) múveleteket végezhetünk. Szükségünk van ilyen jármú röptetése esetén hatósági díjazású drónregisztrációra (az eszköz és az üzembentartó nyilvántartásba vétele is kötelesség) is. Erre a múveleti kategóriára az alábbi általános szabályok vonatkoznak:

- a drón maximális felszállótömege $25 \mathrm{~kg}$;

- emberektôl biztonságos távolságra kell repülnünk;

- ebból következóen nem repülhetünk embertömeg fölött;

- maximum 120 méter magasra távolodhatunk el a földfelszínnek a drónhoz legközelebbi pontjától (kivéve akadály esetén, jogszabályi indokkal);
- a távpilótának a repülés alatt végig látnia kell a drónt (kivéve követési mód vagy megfigyelô személy alkalmazása esetén);

- nem szállíthat veszélyes árut, valamint nem szórhat le semmilyen anyagot.

A nyílt kategóriára vonatkozó egyéb részletek a 2019/947 sz. végrehajtási rendelet mellékletének A részében olvashatók (EU 2019¹).

A szabályozásban 2023. január 1-ig átmeneti idôszak van érvényben. Ennek oka az, hogy a gyártók kötelesek lesznek ekkorra 5 kategóriába (C0/C1) C2/C3/C4) sorolni az UAV-okat. Eddig van idejük felkészülni a törvényben rögzített gyártási feltételekre, valamint osztályba sorolni az eddig forgalmazott eszközöket. Az ehhez kapcsolódó részletszabályok a 2019/945 sz felhatalmazáson alapuló rendeletben (EU 20192) olvashatók. Fontos viszont, hogy a most forgalomban lévô, de 2023-ig osztálybesorolással nem rendelkezô $250 \mathrm{~g}$ feletti felszállótömegú drónok csak A1 és A3 múveleti alkategóriákban repülhetnek majd - ez általánosan vonatkozik az otthon épített, a $25 \mathrm{~kg}$ feletti nem osztálybesorolt és modellgépekre is.

Az A1 múveleti alkategóriába tartoznak a legkönnyebb drónok. Otthon épített eszköz $250 \mathrm{~g}$ alatt, C0 osztályú eszköz $250 \mathrm{~g}$ alatt, C1 osztályú eszköz $900 \mathrm{~g}$ alatt, valamint az átmeneti idôben osztálybesorolás nélküli eszköz $500 \mathrm{~g}$ alatt végezhet tevékenységet ebben a kategóriában. $250 \mathrm{~g}$ MTOM (Maximum Takeoff Mass - teljes felszállótömeg) alatt átrepülhetünk egyének fölött, de ennél nehezebb drón esetében nem szabad olyan területre repülnünk, ahol emberek tartózkodhatnak, embertömeg fölé pedig egyáltalán nem mehetünk. Ha véletlenül mégis emberek közelébe érünk, haladéktalanul, biztonságos módon el kell mozgatnunk a légi jármúvet.

Az A2 múveleti alkategóriában a C2 osztályba tartozó 4 kg-nál kisebb, valamint az átmeneti idôszakban osztálybesorolás nélküli 2 kg-nál könynyebb gépek végezhetnek múveletet. Embertömeg fölé ebben a kategóriában sem repülhetünk, viszont C2 osztályú drónnal 30 m-re megközelíthetünk a múveletbe be nem vont személyeket, amely távolság bekapcsolt alacsony sebességû repülési üzemmód esetén 
vízszintesen mért 5 m-re csökkenthetô az 1:1 szabály (a nem bevont személyektôl olyan vízszintes távolságot kell tartanunk, amilyen magasan repülünk) betartása mellett. Osztálybesorolás nélkül maximum 50 m-re közelíthetünk meg be nem vont személyt.

Az A3 múveleti alkategóriába azok a múveletek tartoznak, amelyek során:

- a légi jármú maximális felszállótömege $25 \mathrm{~kg}$ alatti;

- C2, C3, C4 vagy ezeknek megfelelố osztályba tartozó, otthon épített eszközzel repülünk;

- be nem vont személyekhez közel és föléjük nem repülünk, minimum 30 m távolságot tartunk tőlük az 1:1 szabály értelmében;

- 150 m-es vízszintes távolságot tartunk lakott, kereskedelmi, ipari vagy szabadidôs területtôl;

- a C2 és C3 kategóriájú drónok rendelkeznek aktív közvetlen távoli azonosítási rendszerrel és GPS-szel;

- nem lehet közelebb bevont személy, mint a drón maximális sebességen 2 másodperc alatt megtett útja.
Az 1. táblázatban azt foglaltuk össze, hogy a jelenleg (2023. január 1-ig) osztály nélküli drónok milyen kategóriákban, milyen pilótára vonatkozó feltételekkel reptethetôk. A 2. táblázatban a már osztálybesorolással rendelkezô drónokra összesítettük ugyanezt.

\section{Speciális és engedélyköteles múveleti kategóriák}

Amennyiben embertömeg fölött szeretnénk repülni, áru- vagy személyszállítást szeretnénk végezni, esetleg valamilyen anyagot szeretnénk kiszórni vagy -dobni, minden esetben az engedélyköteles múveleti kategóriába tartozik a tevékenységünk. Erre még szigorúbb (drónnal és pilótával kapcsolatos) követelmények érvényesek, valamint ebben az esetben is az ITM (Innovációs és Technológiai Minisztérium) illetékes a megfeleló engedélyek kibocsájtásáért (Légtér $2021^{2}$ ).

\section{Amit a légtérhasználatról és légtérigénylésról tudni kell}

A megelốzô idôszakhoz képest fontos változás, hogy eseti légtér igénylése csak lakott területen való repülés esetén kötelező (a „játékok” ez alól kivételt képeznek). Eseti légteret legfeljebb 7 napra igényelhetünk úgy, hogy nyilatkozunk a múvelet típusáról (állami/ gazdasági/szabadidôs - ebben a prioritási sorrendben történik az elbírálás). A kérelmet legalább 30 nappal a légtér igénybevétele előtt kell benyújtani a Honvédelmi Minisztérium Állami Légügyi Fốosztályhoz (HM ÁLF), mindezért 9000 Ft igazgatási szolgáltatási díjat kell fizetnünk az ITM részére.

Eseti légtér ugyan nem, de a „mydronespace” mobilalkalmazás használata minden repülés alatt kötelezó (kivéve a „játékokat”). Ebben minden tevékenységünk visszakereshetô és ellenôrizhetô. Az alkalmazást minden repülés elôtt és végig a tevékenység alatt használni kell. Amennyiben nincs hálózat, vagy bármilyen telefonnal

1. táblázat Az osztálybesorolás nélküli drónokkal való nyílt kategóriájú repülés feltételei 2023. január 1-ig - azaz az átmeneti idố alatt (a Légtér 2021' nyomán)

\begin{tabular}{|c|c|c|c|c|c|c|}
\hline Drón & МТOM & $\begin{array}{l}\text { Múveleti } \\
\text { alkategória }\end{array}$ & Megkötések & $\begin{array}{c}\text { Üzembentartó } \\
\text { nyilvántartásba vétele }\end{array}$ & Pilóta képzettsége & $\begin{array}{l}\text { Pilóta min. } \\
\text { életkora }\end{array}$ \\
\hline $\begin{array}{c}\text { Házi } \\
\text { készítés }\end{array}$ & $<250 \mathrm{~g}$ & \multirow[b]{2}{*}{$\begin{array}{l}\text { A1 } \\
\text { (A3-ban is } \\
\text { repülhet) }\end{array}$} & \multirow[b]{2}{*}{$\begin{array}{l}\text { nem repül be nem vont szemé- } \\
\text { lyek és embertömeg közelében }\end{array}$} & $\begin{array}{c}\text { kell, ha a drón nem } \\
\text { „játék” }\end{array}$ & - & 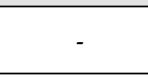 \\
\hline $\begin{array}{l}\text { Osztály } \\
\text { élküli }\end{array}$ & $<500 \mathrm{~g}$ & & & kell & $\begin{array}{l}\text { használati utasítás isme- } \\
\text { rete, múveleti alkategóri- } \\
\text { ának megfelelő képzés és } \\
\text { hatósági vizsga (KTI) }\end{array}$ & 16 \\
\hline $\begin{array}{l}\text { Osztály } \\
\text { nélküli }\end{array}$ & $<25 \mathrm{~kg}$ & A3 & $\begin{array}{c}\text { ne repüljön emberek közelébe, } \\
150 \text { m vízszintes távolságot } \\
\text { kell tartani lakott területtool }\end{array}$ & kell & $\begin{array}{l}\text { használati utasítás isme- } \\
\text { rete, múveleti alkategóri- } \\
\text { ának megfeleló képzés és } \\
\text { hatósági vizsga (KTI) }\end{array}$ & 16 \\
\hline
\end{tabular}

2. táblázat Az osztálybesorolással rendelkezó drónokkal való nyílt kategóriájú repülés feltételei (a „játékokat” kivéve, a Légtér $2021^{1}$ nyomán)

\begin{tabular}{|c|c|c|c|c|c|}
\hline $\begin{array}{c}\text { Múveleti } \\
\text { alkategória }\end{array}$ & Drón & МTOM & Megkötések & Biztosítás & Pilóta képzettsége \\
\hline \multirow{3}{*}{ A1 } & $\begin{array}{l}\text { otthon } \\
\text { épített }\end{array}$ & $<250 \mathrm{~g}$ & \multirow[t]{2}{*}{ átrepülhetünk egyének fölött } & \multirow{2}{*}{$\begin{array}{l}\text { nem kereskedelmi } \\
\text { múvelet esetén nem } \\
\text { kötelező }\end{array}$} & \multirow[t]{2}{*}{ nem kötelezô } \\
\hline & $\mathrm{CO}$ & $<250 \mathrm{~g}$ & & & \\
\hline & $\mathrm{C} 1$ & $<900 \mathrm{~g}$ & $\begin{array}{l}\text { nem repülhetünk be nem vont szemé- } \\
\text { lyek és embertömeg közelében }\end{array}$ & kell & $\begin{array}{l}\text { használati utasítás, mûveleti } \\
\text { alkategóriának megfelelő } \\
\text { képzés és vizsga }\end{array}$ \\
\hline A3 & $\begin{array}{l}\mathrm{C} 2, \mathrm{C} 3, \mathrm{C} 4 \\
\text { vagy megfe- } \\
\text { lelő otthon } \\
\text { épített }\end{array}$ & $<25 \mathrm{~kg}$ & $\begin{array}{c}\text { ne repüljünk emberek közelébe, } \\
150 \text { m vízszintes távolságot kell tartani } \\
\text { lakott területtől }\end{array}$ & $\begin{array}{c}\text { kell }(<250 \mathrm{~g} \text { és } \\
\text { nem kereskedelmi } \\
\text { múvelet esetén nem } \\
\text { kötelezô) }\end{array}$ & $\begin{array}{c}\text { használati utasítás ismerete, } \\
\text { múveleti alkategóriának } \\
\text { megfelelő képzés és } \\
\text { hatósági vizsga (KTI) }\end{array}$ \\
\hline
\end{tabular}


kapcsolatos technikai problémánk van, nem repülhetünk.

Nagyon fontos a biztonságos és szabályos repülés szempontjából a „No Drone Zone" légterek figyelembevétele. Ezek kétfélék lehetnek: olyan tiltott területek, ahol mindig tilos a drónozás (kivéve eseti légtér meglétével, amelyet a vonatkozó engedélyek megszerzése után kaphatunk - 3. táblázat), olyan területek, ahol csak bizonyos időszakokban korlátozott a légtérhasználat - ezek monitorozására is szolgál a „mydronespace” applikáció (Légtér 2021²).

Fontos, hogy eseti légtér igénylésekor $3 \mathrm{~km}$ sugarú körben nem szabad repterek környékét kijelölnünk. Ezen belül minden repülés előtt reptérüzembentartói hozzájárulás és biztonsági felmérés szükséges. Amennyiben nem kell eseti légteret igényelnünk (lakott területen kívül repülnénk), akkor $2 \mathrm{~km}$-en vagy $750 \mathrm{~m}$-en belül reptéri hozzájárulást és ITM-től származó engedélyt kell szereznünk.

\section{Miben módosítják ezek a szabályok a tavaly ószihez} hasonló munkafolyamatot?

Lássuk egy másik példán keresztül, ha egy felmérést napjainkban szeretnénk megtenni, egy másik helyszínen:
- A tervezett helyszín egy természetvédelmi terület (TVT) határán lévô geológiai képzôdmény és egy temetô felmérése egy település határán. Az idôpont 2021 elsố negyede. A feladat: egyetemi kutatás részeként lerepülni és automatikus feldolgozóalgoritmust fejleszteni egy temetôi GIS-alapú sírkataszter készítéséhez, illetve egy geológiai képzôdmény 3D-s modelljének megalkotása UAV-adatok alapján, automatikus klasszifikációs szúrôk fejlesztése és szúrési technikák vizsgálata.

- Az elsố lépés a helyszín kognitív térképezése (vagyis a terepbejárás). A repülési veszélyforrások elemzése (ragadozó madarak, távvezetékek, belógó fák, egyéb akadályozó tényezôk pontos megismerése).

- A következő lépés a vonatkozó engedélyek beszerzése. A helyszín a hatóság térképén részlegesen „belelóg” (párszáz négyzetméter erejéig) egy TVT-be (mindez a légügyi hatóság által használt digitális térkép és az alkalmazott határoló módszer miatt). A Magyar Állami Természetvédelem hivatalos adatbázisa (Agrárminisztérium) szerint a tervezett repülési területünk már nem része a TVT-nek, de a légügyi hatóság az erôsebb szerv. Így a megyei kormányhivataltól kell állásfoglalást és természetvédelmi engedélyt beszerezni (18 000 forint hatósági áron) a tervezett repülés elốtt min. 35 nappal. Ezt kell bemutatni a légügyi hatóságnak is, aki az ideiglenes légtérfoglalásunkat 2021. január 1-tôl már csak maximum 7 napra adja meg.

- Természetesen a légtérfoglalás a fent részletezett szabályok értelmében csak lakott területeken való repülés esetében kötelezố - ez az elốzó példában bemutatott módon történik. Amennyiben légtérre van szükségünk, vegyük figyelembe, hogy a hatósági díj 3000 forintról 9000-re nôtt.

- Fontos szempont, hogy múveletünket és drónunkat el tudjuk helyezni a szabályozás keretrendszerében - a repülésünk csak a megfelelô múveleti kategóriában szabályos. Fontos, hogy tisztában legyünk a magánterületeket érintő fényképkészítés megszigorított jogi körülményeivel is. Amennyiben megfelelünk minden feltételnek, valamint birtoklunk minden engedélyt, kitûzhetjük a felmérés időpontját.

- A légtéraktiválást ugyanúgy a terepi munka megkezdése elôtt jeleznünk kell (a munka befejeztével pedig a deaktiválást). Fontos kiegészítés, hogy a teljes repülés alatt múködnie kell a „mydronespace” mobilalkalmazásnak!

A 2. ábrán a kezdetektől indulva mutatjuk be a folyamatot, amelynek végén szabályosan emelkedhetünk a levegóbe (DOE 2021).

3. táblázat „No Drone Zone” légterek használatának feltételei (a Légtér 2021² nyomán)

\begin{tabular}{|c|c|}
\hline Légtér típusa & Drónos múveletek végzésének lehetôsége \\
\hline Tiltott légtér & $\begin{array}{l}\text { UAV-os múvelet tilos, kivéve a közlekedésért felelős } \\
\text { miniszter egyedi engedélyével }\end{array}$ \\
\hline $\begin{array}{l}\text { Veszélyes légtér és idôszakosan } \\
\text { korlátozott légtér }\end{array}$ & $\begin{array}{l}\text { Múködési idôben nem végezhetô UAS-múvelet, üzem- } \\
\text { idôn kívül az általános szabályok figyelembevételével }\end{array}$ \\
\hline Drop Zone légtér & $\begin{array}{l}\text { Mưködési ideje alatt a koordinációs feladatokat ellátó } \\
\text { szervezet hozzájárulásával, továbbá a távpilóta és a szer- } \\
\text { vezet közötti folyamatos kommunikáció biztosításával }\end{array}$ \\
\hline $\begin{array}{l}\text { Budapest CTR, Kecskemét MCTR, } \\
\text { Szolnok MCTR és Pápa MCTR }\end{array}$ & $\begin{array}{l}\text { No Drone Zone légtéren kívül az általános szabályok } \\
\text { betartása mellett }\end{array}$ \\
\hline $\begin{array}{l}\text { Békéscsaba, Szeged, Nyíregyhá- } \\
\text { za, Pécs-Pogány, Pér, Debrecen } \\
\text { és Sármellék TIZ }\end{array}$ & $\begin{array}{l}\text { A repülőtér üzembentartójának hozzájárulásával, to- } \\
\text { vábbá Debrecen és Sármellék TIZ esetén az illetékes } \\
\text { légiforgalmi szolgáltató hozzájárulásával }\end{array}$ \\
\hline $\begin{array}{l}\text { LHR1 Budapest és LHR1A Buda- } \\
\text { pest korlátozott légterek }\end{array}$ & $\begin{array}{l}\text { A légiközlekedési hatóság engedélyével - } 21 \text { nappal az } \\
\text { igénybevétel előtt benyújtandó a kérelem }\end{array}$ \\
\hline $\begin{array}{l}\text { környezetvédelmi szempontból } \\
\text { korlátozott légterek }\end{array}$ & $\begin{array}{l}\text { A légiközlekedési hatóság engedélyével - } 21 \text { nappal az } \\
\text { igénybevétel előtt benyújtandó a kérelem }\end{array}$ \\
\hline $\begin{array}{l}\text { Polgári légijármúvek számára } \\
\text { korlátozott légterek }\end{array}$ & UAS-múvelet tilos \\
\hline $\begin{array}{l}\text { További korlátozott légterek - } \\
\text { pl. Százhalombatta }\end{array}$ & $\begin{array}{l}\text { A felelős szervezet hozzájárulásával és az ITM-hez tett } \\
\text { előzetes bejelentés legalább } 3 \text { nappal a múvelet elốtt }\end{array}$ \\
\hline $\begin{array}{l}\text { III. osztályú és IV. osztályú repü- } \\
\text { lôterek környezete }\end{array}$ & $\begin{array}{l}2 \text { km-en belül a repülôtér üzembentartójának hozzá- } \\
\text { járulása és bejelentés az ITM-hez } 2 \text { nappal a múvelet } \\
\text { elôtt }\end{array}$ \\
\hline $\begin{array}{l}\text { V. osztályú repülôterek környe- } \\
\text { zete }\end{array}$ & $\begin{array}{l}750 \text { m-en belül a repülôtér üzembentartójának hozzájá- } \\
\text { rulása és bejelentés az ITM-hez } 2 \text { nappal a múvelet eloott }\end{array}$ \\
\hline
\end{tabular}

\section{Összegzés}

Mivel a drónok és az ezeket az eszközöket használó munkafolyamatok száma rohamosan nő, egyértelmú, hogy szükség volt központi szabályozásra. Pozitív törekvés, hogy az Európai Unió szabott meg egységes irányelveket, amelyeket a tagországoknak zömmel követniük kellett. Látnunk kell azonban, hogy az olykor szakmai szempontokat másodlagos fontosságúként kezelô intézkedések nem orvosolják maradéktalanul a felgyülemlő problémákat. Kiemelt fontosságú az emberek épségének és a magántulajon iránti jognak a védelme, de nem szabad elfelejtenünk, hogy a drónozásnak mint múveletcsoportnak számtalan olyan nem feltétlen ipari ágazata van, amelyek túl erôs szabályzása, vagy éppen hiányosan meghatározott keretrendszere sok felhasználót bizonytalan helyzetbe sodor (pl. a speciális és 


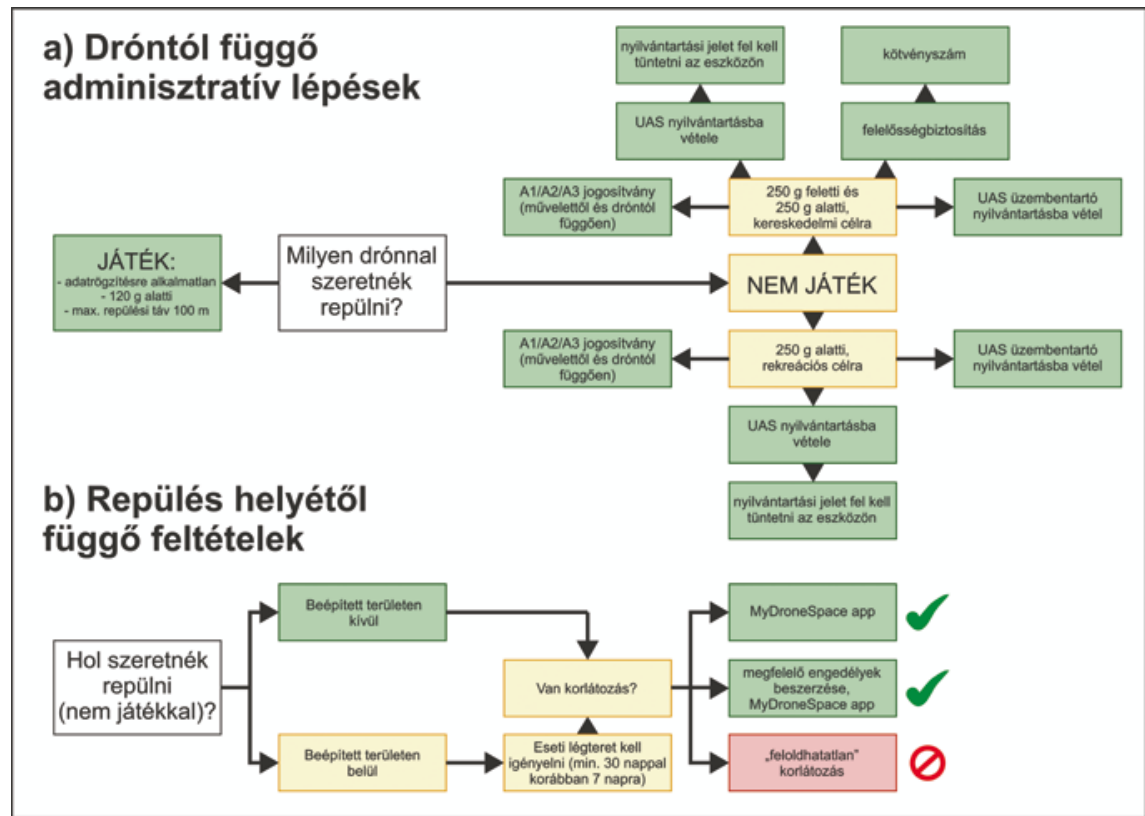

2. ábra. Folyamatábra a nyílt kategóriás múveletek feltételeirôl dróntól a) és repülési helytôl b) függóen

engedélyköteles kategóriák szerény definíciója, követelményrendszere).

Hasonlónak érezzük a saját helyzetünket is, hiszen jelenleg oktatási-kutatási intézményként ugyanolyan követelményrendszer és anyagi terhelés ér bennünket, mint egy hatalmas vállalatot. Ahhoz, hogy hatékonyan tudjunk téradatot gyújteni, feldolgozni, és elsôsorban ehhez értô szakembereket képezni, szükség van bizonyos egyszerúsített feltételekre. Jelen körülmények között a szervezett oktatási keretek között, az egyetem környezetében gyakorlatilag lehetetlen repülni a következó tényezők miatt:

- 30 nappal korábban benyújtandó légtérigénylés;

- az esetlegesen engedélyezett légtér csak 7 napig használható, ami a még kevésbé tervezhetô idôjárás miatt problémás;

- a repterek és más korlátozott légterek miatti engedélykérelem is jelentôs adminisztratív feladat minden igényléskor;

- valamint nem mellốzhetố a mindezek miatt felmerülő anyagi költség.

Üdvözlendô viszont, hogy lakott területen kívül viszonylag egyszerú lett repülni, bár a mobilalkalmazás kötelezó használata sok helyen vethet fel problémát a hálózat hiánya miatt. Értelemszerúen nagyon nehéz minden szempontnak megfelelô jogszabályi környezetet teremteni. Elsôdleges viszont szem elôtt tartani az oktatás-kutatás prioritását: e tevékenység nélkül kevesebb effajta tudással bíró szakember és tudós áll majd rendelkezésre. Épp ezért fontos a párbeszéd és a közös munka.

A munka az EFOP-3.6.3VEKOP-16-2017-00001 és a TKP2020NKA-O6 pályázatok támogatásával készült.

\section{Irodalom}

1995.éviXCVII.törvényalégiközlekedésrôl(Lt.): https://njt.hu/jogszabaly/1995-97-00-00 (utolsó elérés dátuma: 2021.06.14)

2012. évi II. törvény a szabálysértésekrôl a szabálysértési eljárásról és a szabálysértési nyilvántartási rendszerroól (Szabs. tv.) https://njt.hu/jogszabaly/2012-2-00-00 (utolsó elérés dátuma: 2021.06.14)

2012. évi C. törvény a Büntetố Törvénykönyvrôl (Btk.):

https://njt.hu/jogszabaly/2012-100-00-00 (utolsó elérés dátuma: 2021.06.14)

Alex Elliott (2017): Drónok kézikönyve. CSER Kiadó, Budapest / M210 V2 / M210 RTK V2. Online elérhetô felhasználói kézikönyv: https://dl.djicdn. com/downloads/m200 v2/20200630/ M200 Series V2 User Manual en3.pdf (utolsó elérés dátuma: 2021.06.03) Szabályos Drónhasználat folyamatábra A1/A3 Open - tájékoztató jellegű segédlet. Online: https://doe.hu/szabalyosdronhasznalat-folyamatabra (utolsó elérés dátuma: 2021.06.13)

Európai Bizottság (2019) ${ }^{1}$ : 2019/947 Végrehajtási rendelet: https://eur-lex. europa.eu/legal-content/HU/TXT/HTM L/?uri=CELEX:32019R0947\& from $=\mathrm{HU}$ \#d1e2148-45-1 (utolsó elérés dátuma: 2021.06.03)
DJI (2020): MATRICE 200 SERIES V2: M200 V2

Drónpilóták Országos Egyesülete (2021):
Európai Bizottság (2019)2: 2019/945 Felhatalmazáson alapuló rendelet: https:// eur-lex.europa.eu/legal-content/HU/TXT/ HTML/?uri=CELEX:32019R0945\&from $=\mathrm{HU}$ (utolsó elérés dátuma: 2021.06.03)

Légtér $\left(2021^{1}\right)$ : Drónozás nyílt kategóriában. Online: https://legter.hu/blog/ dronozas-nyilt-kategoriaban/ (utolsó elérés dátuma: 2021.06.04)

Légtér $\left(2021^{2}\right)$ : Drón törvény 2021 - érthetôen szakértôktôl. Online:

https://legter.hu/blog/dron-torveny-2021erthetoen-szakertoktol/

(utolsó elérés dátuma: 2021.06.04)

Dr. Palik Mátyás [szerk.] (2013): Pilóta nélküli repülés profiknak és amatốröknek. Nemzeti Közszolgálati Egyetem

Major Krisztina, Kozma-Bognár Veronika, Enyedi Attila, Váradi Ádám \& Berke József (2016): Távirányítású drónok kutatási célú vizuális adatainak alkalmazása az oktatásban. XXII. „Multimédia az Oktatásban” nemzetközi konferencia, Keszthely.

MicaSense (2020): MicaSense Altum ${ }^{\mathrm{TM}}$ and DLS 2 Integration Guide. Online felhasználói kézikönyv: https://support.micasense. com/hc/en-us/articles/360010025413Altum-Integration-Guide-PDF(utolsó elérés dátuma: 2021.06.03)

Restás Ágoston (2017): A drónok közszolgálati alkalmazásának lehetôségei. Új magyar közigazgatás. KÖZSZÖV, Gödöllô, 10:3, pp. 49-63.

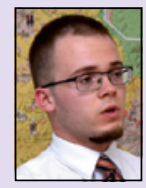

Pál Márton

doktorandusz

ELTE Földtudományi Doktori Iskola ELTE IK Térképtudományi és Geoinformatikai Intézet marchello@map.elte.hu

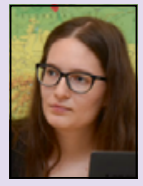

Hajdinákné Vörös Fanni doktorandusz

ELTE Földtudományi Doktori Iskola ELTE IK Térképtudományi és Geoinformatikai Intézet vorosfanni@map.elte.hu

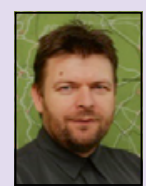

\section{Dr. Kovács Béla} egyetemi adjunktus

ELTE IK Térképtudományi és Geoinformatikai Intézet climbela@map.elte.hu 